\section{Low-oxygen Atmosphere Suppresses Flowering in Chilling-satisfied Blueberries}

\author{
D.J. Makus ${ }^{1}$ \\ U. S. Department of Agriculture, Agricultural Research Service, \\ Booneville, AR 72927
}

Additional index words. Vaccinium, dormancy, modified atmosphere applied dormant oil sprays in delaying bloom in peaches suggests a mechanism for the reported delay based on retardation of gas diffusion through buds (Call and Seeley, 1989).

In the southeastern United States, southem highbush (Vaccinium corymbosum L.) and rabbiteye ( $V$. ashei Reade) deacclimated fruit buds and flowers frequently have been damaged by late spring freezes, resulting in lost income to producers. Attempts to date to delay flowering in rabbiteye by use of ethephon and fall pruning have not 'been successful (Makus, 1988).

The following study explores the effect of reduced-oxygen atmosphere on the time of flowering in two blueberry species that had received adequate winter chilling.

Seven-year-old blueberry plants, highbush selection 'NC 1409', and rabbiteye selection 'T-152', were dug from a field selection trial in Booneville, Ark., in mid-Feb. 1990, moved to a $30 \%$ shaded screenhouse, and then each plant was pruned into three equal sections. Each section had typically 60 to 120 fruit buds with no leaves present. A frame was installed over the plants, then covered with white plastic on the top and black plastic on the east, south, and west sides to minimize direct and reflected light into the plant canopies.

On 20 Feb., plants had received 800 chillhours (Utah model). Three gas environments were established on each plant: ambient air (control), breathing-quality air delivered by tubing into a clear plastic bag enclosing about one-third of the plant, or high purity $\mathrm{N}$ (99.99\%) delivered by tubing into a similar bag enclosing the remaining one-third of the plant. The purpose of the air/bag treatment was to observe any thermal or partial pressure effects of the bag. Gas flows were sufficient to keep the bags under positive pressure and to continually purge internal atmospheres. There were three plants per replication of each selection. Bud development (Spiers, 1978) was recorded at the inception of the experiment (20 Feb.) and then at 14-

Received for publication 22 Jan. 1991. The cost of publishing this paper was defrayed in part by the payment of page charges. Under postal regulations, this paper therefore must be hereby marked advertisement solely to indicate this fact.

'Research Horticulturist.
A recent report on the effect of late winterday intervals until $17 \mathrm{Apr}$
Gas composition in the N/bag treatment was not verified; it may have contained a trace of 0 ,

Flower bud development in both blueberry types was suppressed by the low-O, atmosphere (Fig. 1). The presence of the plastic bag enclosure had no appreciable effect on flower bud development. The rabbiteye selection was significantly more advanced in bud development than the highbush plants throughout the experiment. There was no treatment $\times$ species interaction, but the treatment $\times$ date and treatment $\times$ species $x$ date interactions were significant.

Flowering on $17 \mathrm{Apr}$., pooled over species, had reached $84.0 \%, 84.3 \%$, and $0.7 \%$ for the ambient air, air/bag and N/bag treatments, respectively. The mean flowering percentages in air and air/bag treatments were $\approx 5 \%$ lower in 'NC 1409' than in ' $\mathrm{T}-152$ ', but means were not statistically different (Table 1). The low- $\mathrm{O}_{2}$ atmosphere significantly reduced the percentage of buds in flower on 17 Apr. in both species. After a normal atmosphere was restored, on $17 \mathrm{Apr}$., buds previously under low $\mathrm{O}_{2}$ showed a 3to 4-week delay in the dates of $10 \%$ and $50 \%$ bloom, respectively. In $V$. corymbosum, but not $V$. ashei, dates at $10 \%$ and $50 \%$ bloom for fruit buds kept in air/bags were delayed compared with controls (ambient air).

Vegetative budbreak was greatly impeded but not completely blocked by low $\mathrm{O}_{2}$. The presence of bags during flowering and the absence of pollinators precluded a comparison of subsequent fruit set.

\section{Literature Cited}

Call, R.E. and S.D. Seeley. 1989. Flower bud coatings of spray oils delay dehardening and bloom in peach trees. HortScience 24(6):914915.

Makus, D.J. 1988. Attempts to delay flowering in rabbiteye blueberry cultivars. Proc. Ark. State Hort. Soc. 109:79-84.

Spiers, J.M. 1978. Effect of stage of bud develJ. Amer. Soc. Hort. Sci. 10(4):452-455.

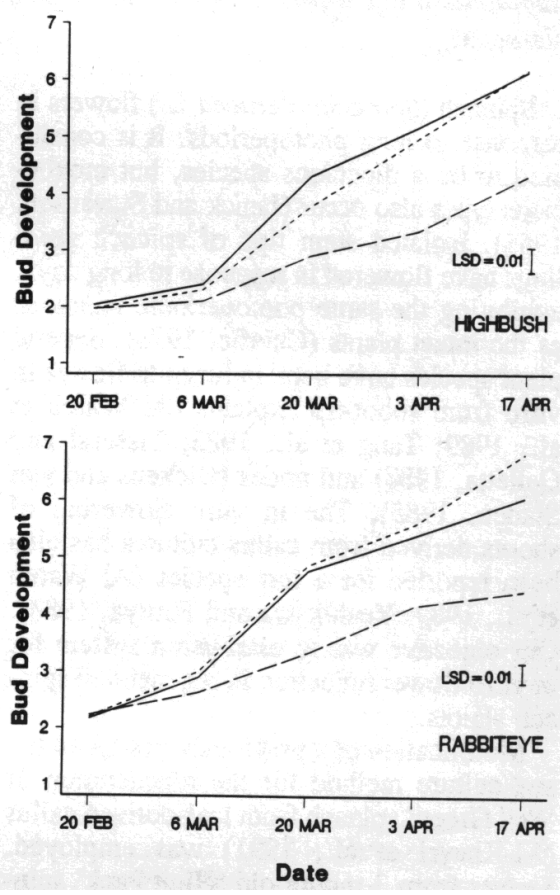

Fig. 1. Fruit bud development as affected by a low- $\mathrm{O}_{2}$ atmosphere in chill-satisfied blueberry plants. Comparison of means at each date showed that all differences between air treatments occurring 14 days (rabbiteye only) or later (both species) following initiation of low-O $(-$ - - -) atmospheres were significant $(P<$ 0.01 ). Control (ambient air, - ) and air (in bags, -----) treatments differed $(P<0.01)$ on 20 Mar. (highbush only) and 17 Apr. (rabbiteye only). On a scale of 1 to $7,6=$ full bloom. opment on cold injury in rabbiteye blueberry.

Table 1. Percent flowering on 17 Apr. 1990 and average bloom date for $10 \%$ and $50 \%$ bloom after subjecting Vaccinium corymbosum and $V$. ashei buds to three gas environments.

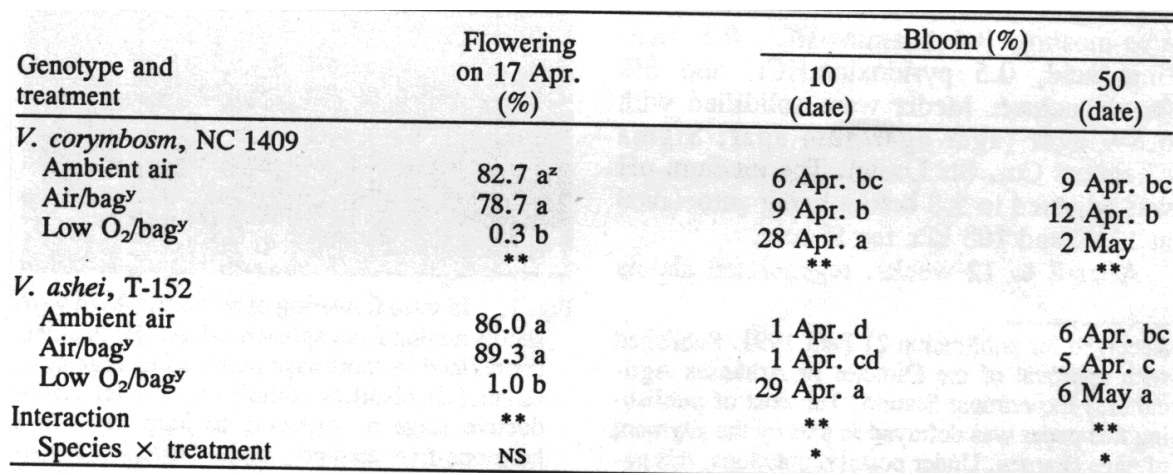

${ }^{2}$ Means of three replications separated by LSD (0.01 or 0.05$)$. Mean separation within columns. ${ }^{y}$ Bags were removed on $17 \mathrm{Apr}$.

Nonsignificant or significant at $P=0.05$ or 0.01 , respectively. 